\title{
Expressions of the Cell Cycle Relative Proteins in Esophageal Cancer Tissues
}

\author{
Sara Khodahemmati ${ }^{1}$, Jintao $\mathrm{Li}^{1}{ }^{*}$, Hongwei Liu ${ }^{2}$, Maliha Ghaffar ${ }^{1}$, Yangjunqi Wang ${ }^{1}$, \\ Zhixiang Zhou', Yi Zeng1,3*
}

${ }^{1}$ Beijing Key Laboratory of Environmental and Viral Oncology, College of Life Science and Bio-Engineering, Beijing University of Technology, Beijing, China

${ }^{2}$ Department of Life Science, China West Normal University, Nanchong, China

${ }^{3}$ State Key Laboratory of Infectious Disease Prevention and Control, National Institute for Viral Disease Control and Prevention, Chinese Center for Disease Control and Prevention, Collaborative Innovation Center for Diagnosis and Treatment of Infectious Diseases, Beijing, China

Email: ^Ljt2008@bjut.edu.cn, *zengyicdc@sina.com

How to cite this paper: Khodahemmati, S., Li, J.T., Liu, H.W., Ghaffar, M., Wang, Y.J.Q., Zhou, Z.X. and Zeng, Y. (2018) Expressions of the Cell Cycle Relative Proteins in Esophageal Cancer Tissues. Journal of Cancer Therapy, 9, 857-871.

https://doi.org/10.4236/jct.2018.911071

Received: September 18, 2018

Accepted: November 10, 2018

Published: November 13, 2018

Copyright $\odot 2018$ by authors and Scientific Research Publishing Inc. This work is licensed under the Creative Commons Attribution International License (CC BY 4.0).

http://creativecommons.org/licenses/by/4.0/

(c) (i) Open Access

\begin{abstract}
The aim of the research is to investigate the expression of the cell cycle relative proteins (P53, P16, Cyclin D1, and Ki67) in Esophageal Cancer (EC) patients of the Chaoshan area, China. In China, Chaoshan has the high incidence of EC. Different areas have shown different rate for expression of these proteins in EC. We investigated the expression of p53, p16, cyclinD1, and ki67 for the first time in Chaoshan. In this research, DNA was extracted from formalin fixed and paraffin embedded tissues of esophageal cancer (EC) patients. The expression level of proteins cycle was detected by using immunohistochemistry (IHC). And the data was checked by $\chi^{2}$ test or Fisher's exact test of SPSS17.0. The positive immunohistochemical staining of p53, p16, cyclinD1, and ki67 were observed in $65.7 \% 39.2 \%, 69.1 \%$, and $83.5 \%$ specimens respectively. There was a positive correlation between p53 positive staining and $\mathrm{p} 16$, cyclinD1, ki67 staining at $\mathrm{p}<0.05$. CyclinD1 has the high correlation with ki67 at $\mathrm{p}<0.05$. A significant inverse correlation was considered between the expression of $\mathrm{p} 16$ and cyclinD1 and there was no correlation observed between p16 and ki67. In Conclusion, this study demonstrated the high expression of p53, Cyclin D1 and Ki67 and low expression of P16 and the association of these cell cycle relative proteins in esophageal cancer are new data in Chaoshan area of China. Geographical distribution of EC on the molecular basis is revealed in this research.
\end{abstract}

\section{Keywords}

Esophageal Cancer, Regulatory Pathway, P53, P16, CyclinD1, ki67 


\section{Introduction}

Esophageal Cancer (EC) is ranked as the eighth most common cancer globally and is at number six because of causing death [1]. Most of the EC cases occur in Asia, especially some areas of China having high incidence like Linxian and Huixian counties of Henan area [2]. Many genetic and environmental factors are considered as a cause of EC [3] [4].

Wang Lidong demonstrated two EC susceptibility genes, i.e. Asian phospholipase gene type (PLCE1) and riboflavin hormone transporter gene (C20orf54), by using genome-wide association analysis on chromosome No. 10 of human beings [5]. It is widely accepted that tumorigenesis is a complex and multi-step process that takes place when tumor suppressor genes are inactivating, and oncogenes are activated [6]. Like other cancers, EC is also a complex of a multi-step process which involves many regulatory factors along with many oncogenes and tumor suppressor genes.

Different molecular events are associating with EC which take place sequentially or simultaneously and their combined effect causes disorder in cell cycle by disturbing cell cycle regulation mechanism which leads to malignancies with aggressive and uncontrolled cell proliferation. Some proteins can help in the diagnosis and treatment of tumors because of their important role in the regulation of the cell division cycle [7], and they also participate in different regulatory pathways within cells. Still, a lot of research is required to conquer the disease. In the current cancer research, two proteins, $\mathrm{p} 53$, and pRb play a key role in cell cycle pathways. In this case, p53 showed different expression rate in the different area $[8]$.

P53 is a tumor suppressor protein which plays a key role to decide the fate of the cell with the help of its function as a key part of cellular signaling pathways [6]. During tumorigenesis, all the altered cellular processes within the cancer cell or outside the cell, in the surrounding environment, are controlled by p53 gene. p53 gene is located on chromosome 17q13.1. [9], and plays an important role as tumor suppressor gene in the regulation of cell cycle, the stability of genome, cell differentiation as well as in apoptosis and finally, to cellular immortalization [10]. Transcriptional activation of wild-type p53 gene is required for a proper response after DNA damage, apoptosis or cell cycle arrest [11]. Therefore protein encoded by wild-type p53 gene is called tumor suppressor protein while protein produced as the result of mutation is abnormal and plays an important role in tumor formation in human [12] [13] [14]. Normal protein function of p53 is inactivated and its abnormal expression takes place when the mutation in p53 occurs which ultimately becomes the reason of cancer protein formation, which causes escape from the cell cycle regulation [14] [15]. The normal protein encoded by wild-type p53 gene cannot be detected by conventional methods used for its detection because it is accumulated in normal cells in very low amounts and can be easily degraded as this normal protein has the short lifespan with the half-life of about 30 minutes. While mutant protein can be detected eas- 
ily by conventional methods as it is accumulated in large amounts in cells and cannot be easily degraded because of structural changes in mutant as well as extension in its half-life. To explore the effects of functional inactivation of p53 on the formation of esophageal cancer, we need to use immunohistochemistry experiments for detection of $\mathrm{p} 53$ protein expression in cells in EC.

p53 degradation interferes with the function of $\mathrm{pRb}$, leads to upregulation of p16 due to loss of negative feedback control [16] [17]. P16 gene is the tumor suppressor gene which regulates the cell cycle with its direct participation in cell cycle and by negatively regulating the process of cell proliferation and division. This gene is also known as MTS (multiple tumor suppressors 1) gene, [18] [19]. P16 gene encodes a $16 \mathrm{kD}$ protein, which is an inhibitor of cyclin-dependent kinase 4 (CDK4) therefore it is also called (CDKI). P16 inhibits the cell from G1 phase to $S$ phase by inhibiting the formation of CDK4 and cyclinD1 complex [18] [20].

Beside these tumour suppressor genes, there is a nuclear protein by the name of Ki67 which is associated with cell proliferation because observed during activate phases of the cell cycle from G1 phases to mitosis but not resting cell [21] [22].

However the molecular expression of the p53, p16, cyclinD1, ki67 proteins have been extensively investigated in different cancers and areas, but there is no research available for these cell cycle relative proteins and relationship together inesophageal cancer in Chaoshan area of China.

This research is conducted to investigate the expression of p53, p16, cyclinD1, ki67 protein molecules by immunohistochemistry in esophageal surgical tissue in the Chaoshan area. It will help to explore the molecular events involved in disease progression of EC in specifics area.

\section{Material and Method}

\subsection{Collection of Specimens and DNA Extraction}

Esophageal cancer specimens were obtained from surgical resection tissues which were pathologically diagnosed as esophageal cancer in the Department of Pathology, Jieyang People's Hospital of Guangdong Province from 2011 to 2013. A total of 279 cases were reported. This specimen is a formalin-fixed paraffin-embedded tissue mass. The researchers cut $3 \mu \mathrm{m}$ thick tissues for immunohistochemistry. Registration of patients' names, age and other basic information, electronic archiving. The average age of 279 esophageal cancer cases collected in this experiment is $63 \pm 8$, the ratio of male to female is 1.9:1.

\subsection{Immunohistochemically}

279 slices in $2-3-\mu \mathrm{m}$-thick were cut from paraffin-embedded samples then these slices were dewaxed with xylene after depositing on coated glass slides. After this, the slides were washed with ethanol and incubated in $0.3 \% \mathrm{H}_{2} \mathrm{O}_{2} /$ methanol (30 $\mathrm{min})$. Then specimens were incubated in $0.01 \mathrm{~mol}$ sodium phosphate/citrate 
buffer $(\mathrm{pH} 8.0)$ at $95^{\circ} \mathrm{C}$ in a microwave oven $(5 \mathrm{~min})$. After this, slides were incubated with $5 \%$ bovine serum albumin (BSA) in phosphate buffered saline (PBS) at room temperature (30 $\mathrm{min}$ ) in order to avoid the nonspecific binding of the antibody. A 1:200 dilution in 5\% BSA-PBS of monoclonal anti-p16INK4a antibody was used (BD PharMingen, San Jose, CA, United States). Then the specimens were incubated at $4^{\circ} \mathrm{C}$ (overnight). The slides were again incubated for 30 min with biotinylated horse anti-mouse IgG and washed with PBS before and after incubation. Then avidin-biotin-peroxidase complex (Vectastain Elite ABC kit; Vector Laboratories, Burlingame, CA, United States) with 1:50 dilution was used for incubation at room temperature $(30 \mathrm{~min})$. Diaminobenzidine (Dako, Carpinteria, CA, United States) was added for $10 \mathrm{~min}$ to visualize the reaction. Specimens were visualized after counterstaining of sections with Hematoxylin. Immunostaining of $10 \%-100 \%$ cells was considered positive while $0 \%-9 \%$ cells were considered negative, according to criteria reported previously [23] [24].

The same procedure was used for p53, cyclinD1, and ki67 as for p16INK4a. The interpretation of the positive signal was also same as p16INK4a immunostaining.

\subsection{Statistical Analyses}

SPSS17.0 (SPSS Inc., Chicago, IL) was used for statistical analysis. The presence of protein in EC tissues and normal esophageal tissue was analyzed by Chi-square test and Fisher's test. For comparison of the expression of p53, p16, cyclinD1, ki-67 protein and the relationship between the four proteins was done with Linear regression analysis. $\mathrm{p}<0.05$ was used to show statistically significant results.

\section{Results}

\section{EC Tissue Specimens and p53, p16, Cyclind1, ki67 Protein Expression}

In this study, the expression of four proteins (p53, p16, cyclinD1, and ki67) was investigated in a total of 279 samples. For immunohistochemical analysis, out of 279 samples, 268 samples were used for p53 and ki67 while 265 samples were used for p16 and cyclinD1. Protein intensity of p53, p16, cyclinD1, ki67 and their location in the cell was evaluated by using Biemer-huttmann AE standard. The staining less than $5 \%$ was scored as negative $(-), 5 \%-20 \%$ as weak positive $(+), 20 \%-50 \%$ as positive $(++)$ while more than $50 \%$ was considered as strongly positive $(+++)(29)$. And the result for P53, P16, cyclinD1 and ki67 were $(65.7 \%, 39.2 \%, 69.1 \%$ and $83.5 \%$ respectively) as shown in (Table 1, Figure 1(a)).

Out of 265 specimens, 161 were immuno-negative and assigned 0 points for immunohistochemical results; 38 were weakly immunopositive and assigned 1 point; 35 were strongly positive in the immune system and assigned a value of 2 

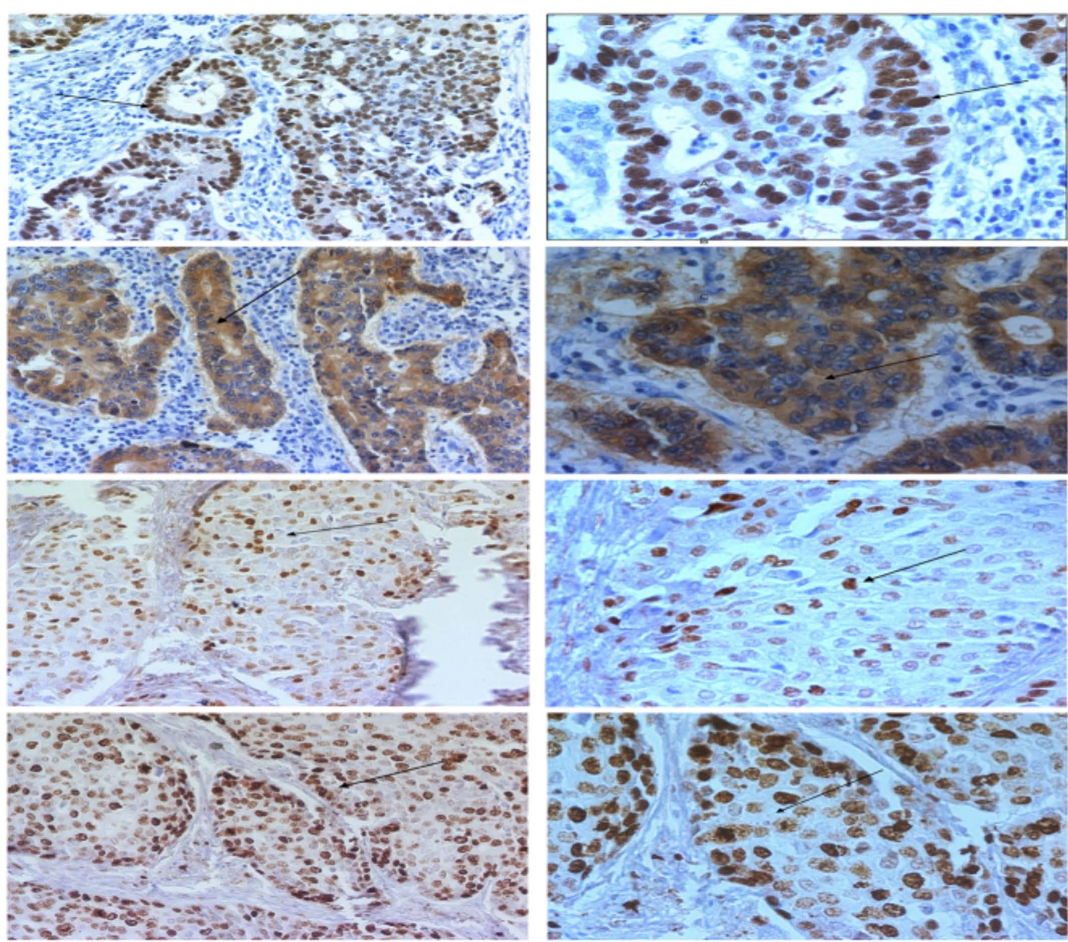

(a)

Figure 1. The positive immunohistochemically staining for P53, P16, CyclinD1 and Ki67 by IHC $(\times 200,400)$ : (a) The immunohistochemically staining of P53; (b) The immunohistochemical staining ofP16; (c) The immunohistochemical staining of CyclinD1; (d) The immunohistochemical staining of Ki67.

Table 1 . The summary of p53, p16, cyclinD1, and ki67 immunohistochemically staining.

\begin{tabular}{|c|c|c|c|c|c|c|c|}
\hline \multirow{2}{*}{$\begin{array}{c}\text { IHC } \\
\text { Index }\end{array}$} & \multicolumn{5}{|c|}{ Immune response } & \multirow{2}{*}{$\begin{array}{c}\text { The overall } \\
\text { positive Rate (\%) }\end{array}$} & \multirow{2}{*}{$\begin{array}{c}\geq++ \text { positive } \\
\quad \text { Rate }(\%)\end{array}$} \\
\hline & - & + & ++ & +++ & Total & & \\
\hline P53 & 92 & 44 & 71 & 61 & 268 & $65.7 \%$ & $49.3 \%$ \\
\hline P16 & 161 & 38 & 35 & 31 & 265 & $39.2 \%$ & $24.9 \%$ \\
\hline CyclinD1 & 82 & 71 & 68 & 44 & 265 & $69.1 \%$ & $42.3 \%$ \\
\hline Ki67 & 44 & 85 & 101 & 38 & 268 & $83.5 \%$ & $51.9 \%$ \\
\hline
\end{tabular}

points; 31 cases had a strong immune response. Positive, assigned 3 points. Immuno-positive cells of P16 are characterized by a yellow to brownish yellow cytoplasm and some nuclear staining. A total of 104 tissue samples were positive for the immune response, with a positive rate of $39.2 \%$ as shown in Table 1 and Figure 1(b).

Out of the 265 cyclinD1 immunohistochemistry results, 82 were found negative for the immune response and assigned 0 points; 71 were positive for the immune response and assigned 1 point; 68 were moderately positive for the immune response and assigned 2 points; 44 were strongly immunopositive, Assignment 3 points. The cyclinD1 immunoreactive cells stained for nuclei with a $\tan$ color. A total of 183 samples were positive for the immune response, with a positive rate of $69.1 \%$, as shown in Table 1 and Figure 1 (c). 
Out of the 268 ki67 immunohistochemical results, 44 were negative for the immune response and assigned 0 points; 85 were positive for the immune response and assigned 1 point; 101 were moderately positive for the immune system and assigned 2 points; 38 cases.

Strong positive for immune response, assigned 3 points. The immune-positive cells of Ki67 stain the nuclei with a tan color. A total of 224 samples were positive for the immune response, with a positive rate of $83.5 \%$, as shown in Table 1 and Figure 1(d).

Statistical analysis showed that the immune response of $\mathrm{p} 53$ protein was positively correlated with p16 protein immunoreactivity, and the correlation coefficient of Pearson was 0.27, p $=0.00$ (Table 2). Among them, 83 (31.7\%) specimens showed co-positive immune response of p53/p16, 70 cases (26.7\%) showed p53/p16 negative immune response, 90 cases (34.4\%) showed p53 immunoreactive/p16 negative, 19 cases $(7.3 \%)$ showed p53 immunologic negative/p16 positive.

The immunoreactivity of P53 protein was positively correlated with cyclinD1 immunoreactivity, and the correlation coefficient of Pearson was $0.18, \mathrm{p}=0.00$ (Table 3). Among them, 124 cases (48.6\%) were p53/cyclinD1 immunoreactive, 31 cases $(12.2 \%)$ were p53/cyclinD1 negative, 43 cases $(16.9 \%)$ had p53 positive/cyclinD1 negative, 57 cases (22.4\%) showed p53 negative/cyclinD1 positive.

P53 protein immunoreactivity was positively correlated with Ki67 protein immunoreactivity, Pearson correlation coefficient was $0.26, \mathrm{p}=0.00$ (Table 4). Among them, 152 cases (58.9\%) were p53/ki67 protein immunoreactive positive,

Table 2. Correlation analysis of P53 immune response and p16 immune response.

\begin{tabular}{cccc}
\hline & & P16 & P53 \\
\hline P16 & Pearson Correlation & 1 & $0.273^{\star *}$ \\
& Sig. (2-tailed) & & 0.000 \\
& $\mathrm{~N}$ & 265 & 263 \\
P53 & Pearson Correlation & $0.273^{\star *}$ & 1 \\
& Sig. (2-tailed) & 0.000 & 268 \\
\hline
\end{tabular}

Table 3. Correlation analysis of P53 immune response and CyclinD1 immune response.

\begin{tabular}{cccc}
\hline & & P53 & CyclinD1 \\
\hline & Pearson Correlation & 1 & $0.181^{* *}$ \\
P53 & Sig. (2-tailed) & & 0.004 \\
& $\mathrm{~N}$ & 268 & 255 \\
CyclinD1 & Pearson Correlation & $0.181^{* *}$ & 1 \\
& Sig. (2-tailed) & 0.004 & 265 \\
\hline
\end{tabular}


26 cases $(10.1 \%)$ were p53/ki67 protein immunoreactive negative, 15 cases (5.8\%) were p53 positive/ki67 negative, 65 cases (25.2\%) were p53 negative/ki67 positive.

Statistical analysis showed that the immune response of p16 protein was negatively correlated with the cyclinD1 protein immunoreactivity, and the correlation coefficient of Pearson was -0.20 and $\mathrm{p}=0.00$ (Table 5). Among them, 61 cases $(23.9 \%)$ were p16/cyclinD1 immunopositive, 37 cases (14.5\%) were p16/cyclinD1 immunonegative, 38 cases (14.9\%) were p16 immunopositive/cyclinD1 negative, 119 cases $(46.7 \%)$ were p16 immunopositive negative/cyclinD1 positive.

CyclinD1 protein immunoreactivity was positively correlated with Ki67 protein immunoreactivity, Pearson correlation coefficient was $0.28, \mathrm{p}=0.00$ (Table 6). Among them, 169 cases (64\%) were immunopositive with cyclinD1 immunoreactive/ki67, 27 cases (9.1\%) were immunological negative, 14 cases $(5.3 \%)$ were cyclinD1 immunpositive/ki67 negative, 54 cases $(20.5 \%)$ were cyclinD1 immunopositive negative/ki67 positive.

There was no correlation between P16 protein immunoreaction and Ki67 protein immunoreactivity, Pearson correlation coefficient was $0.03, p=0.62>$ 0.05 (Table 7).

These statistical analyses revealed that there was a positive correlation between $\mathrm{p} 53$ positive staining and $\mathrm{p} 16$, cyclinD1, ki67 staining at $\mathrm{p}<0.05$. CyclinD1 has the high correlation with ki67 at $\mathrm{p}<0.05$. A significantly inverse correlation was found between the expression of p16 and cyclinD1 but no correlation was found between p16 and ki67.

Table 4. Correlation analysis of P53 immune response and Ki67 immune response.

\begin{tabular}{cccc}
\hline & & P53 & Ki67 \\
\hline \multirow{2}{*}{ P53 } & Pearson Correlation & 1 & $0.258^{* *}$ \\
& Sig. (2-tailed) & & 0.000 \\
& $\mathrm{~N}$ & 268 & 258 \\
Ki67 & Pearson Correlation & $0.258^{* *}$ & 1 \\
& Sig. (2-tailed) & 0.000 & 268
\end{tabular}

Table 5. Correlation analysis of P16 immune response and CyclinD1 immune response.

\begin{tabular}{cccc}
\hline & & P16 & CyclinD1 \\
\hline \multirow{3}{*}{ P16 } & Pearson Correlation & 1 & $-0.199^{* *}$ \\
& Sig. (2-tailed) & & 0.001 \\
& N & 265 & 255 \\
CyclinD1 & Pearson Correlation & $-0.199^{* *}$ & 1 \\
& Sig. (2-tailed) & 0.001 & \\
& N & 255 & 265
\end{tabular}


Table 6. Correlation analysis of CyclinD1 immune response and Ki67 immune response.

\begin{tabular}{cccc}
\hline & & CyclinD1 & KI67 \\
\hline PyclinD1 & Pearson Correlation & 1 & $0.282^{* *}$ \\
& Sig. (2-tailed) & & 0.000 \\
& N & 353 & 350 \\
Ki67 & Pearson Correlation & $0.282^{* *}$ & 1 \\
& Sig. (2-tailed) & 0.000 & 354 \\
\hline
\end{tabular}

Table 7. Correlation analysis of Ki67 immune response and P16 immune response.

\begin{tabular}{cccc}
\hline & & Ki67 & P16 \\
\hline \multirow{2}{*}{ Ki67 } & Pearson Correlation & 1 & 0.027 \\
& Sig. (2-tailed) & & 0.617 \\
& N & 354 & 350 \\
P16 & Pearson Correlation & 0.027 & 1 \\
& Sig. (2-tailed) & 0.617 & \\
& N & 350 & 364 \\
\hline
\end{tabular}

\section{Discussion}

This study focused on expressions of the proteins (p53, p16, cyclinD1, and ki67) and relationships of these proteins together among esophageal cancer in Chaoshan area of Guangdong, China.

The different relationship between p53, p16, cyclinD1, and ki67 in expressions and in different cancers. [25] [26] [27] [28] [29] this difference even observed in subgroups of cancers [30].

In esophageal cancer, even the overexpression of P53, Cyclin D1 and Ki67 and loss of expression of p16 have shown a similar regulation pattern [31] [31], but the expression rates of the proteins were different compared with our results. This variation in rates of protein expression may correlate with clinic opathologic factors [30] or due to area and ethnicity of the population studied [31] [32] [33].

In ESCC, the rate of expression of tp53 has shown variation in different areas. There are significant geographical differences found in expression p53 especially among Western and Chinese patients as well as different areas of China [34] [35].

Our results show the high rate of tp53 expression in EC patients of Chaoshan, China. These results are similar as documented previously in other areas of China as compared to Western areas [8]-[34]. The result of the present study is $65.7 \%$ and this rate is nearly similar to previously documented in Chinese patients study by Dong-Yu Wang which was 64\% [34]. The results of this study are different from other studies as our results show a higher percentage than the 
study from the Guangzhou and Shenyiang with $51.4 \%$ while studies from other areas have shown higher percentage like Huixian and Linxian with 80.9. Geographic variation may be one of the reasons for this variation in prevalence of p53 protein expression or other etiologic factors associated with high incidence of EC [34] [35].

This study showed $65.7 \%$ p53 positive expression, suggesting that most of the incidence of EC is related with abnormal expression of p53 protein. revealed the other studies that the $\mathrm{p} 53$ protein was increased with the increase in the degree of dysplasia [36].

p21 protein exhibited strong immunoreactivity in the immune response of p53-negative. It can be assumed that $\mathrm{p} 21$ protein is a downstream target protein. p53 protein plays a vital role in cell regulation pathway which is $\mathrm{p} 53$-dependent, so the regulation of former is induced by the later [37]. p21 protein cannot be induced to express in cells which have abnormal p53 function therefore, it cannot be detected which results in cell division and proliferation. In addition, p21 rely on CDKI which is an important member of the kinase family inhibitors. [38]. CyclinD1 protein expression level will rise in cells in contrast with low p21 expression. This causal logic can easily explain the experimental results in p53 immunoreactivity. In this experiment, The phenomena of CyclinD1 immune response was positively correlated and strong immune p53 positive cells also show cyclinD1 immunoreactivity. $34.3 \%$ of EC specimens showed negative p53 protein immune response. These tumors carcinogenic mechanisms are different from former due to different regulatory pathways, which may not be involved in p53. Mutated $\mathrm{Rb}$ gene and inactivation of the p16 gene may replace the functional inactivation of $\mathrm{p} 53$ in esophageal lesions.

$39.2 \%$ of the tissue samples showed p16 protein immunoreactivity. Only $24.9 \%$ showed strong immune responses and most of the remaining manifestations negative immune. The more interesting results in our research are the significant negative correlation of cyclinD1 with p16 immunoreactivity immune response. Significant negative correlation is found in Immunoreactivity. Most of the specimens are found to have p16-negative and weak positive immune reactions. CyclinD1 showed positive or strong positive immune response. The reason is that p16 gene deletion and functional inactivation of cyclinD1 is inhibited which results in increased levels of cyclinD1 protein expression [39] [40]. These results indicate that high expression or lack of expression of p16 protein and cyclinD1 is common in presence of EC and the combining effect of both may accelerate tumorigenesis. In addition to the performance of p16 immunonegative/cyclinD1 immunoreactive tumor, there are also third characteristics of tumor immune response exhibited by p16/cyclinD1. They may also differ in carcinogenic mechanisms and pathways. Such as p16 immunopositive tumors, these tumors may occur when there are mutation and inactivation of tumor suppressor gene $\mathrm{Rb}$. Abnormality of $\mathrm{Rb}$ genes is detected in many documents of soft tissue sarcoma in esophageal cancer, breast cancer, small-cell lung cancer. Presence of p16 protein expression in the tumor cells is also observed at the 
same time [41] [42]. Negative feedback loop model is proposed about pRb, p16 to explain this phenomenon. Under normal circumstances, $\mathrm{pRb}$ play role of phosphorylation through cyclinD1-CDK4 complex which leads to inactivation of $\mathrm{pRb}$ then induce transcription of $\mathrm{p} 16$ gene and corresponding protein is expressed and there is competitive binding of p16 protein and Cyclin D with $\mathrm{CDK} 4$. Inhibition of $\mathrm{Rb}$ protein phosphorylation results in dephosphorylation of the $\mathrm{Rb}$ protein to remain active state and anti-p16 transcription by inhibiting transcription and expression [37] [39]. This negative feedback regulatory pathway is damaged when the $\mathrm{Rb}$ gene has mutations and is inactive. Transcription of $\mathrm{p} 16$ gene cannot inhibit $\mathrm{Rb}$, so the $\mathrm{pRb}$ protein expression or low expression of $\mathrm{p} 16$ protein will not be expressed in cells.

However the relation between Ki67 and P53, CyclinD1 and P16 is not well understood and there is no direct reaction between Ki67 and cell cycle proteins, CyclinD1 and P16, Figure 2 (https://string-db.org), our result demonstrates that the high correlation between this protein and P53 and CyclinD1 and no correlation of Ki67 and P16. but the more future study will suggest to explain the relationship between these proteins. 83.5\% EC specimens showed ki67 protein and is the highest among four molecular markers which are found positive in the present study, but there is no ki67 immunoreactivity in corresponding normal tissues, suggesting that ki67 protein is highly expressed only in EC cells.

\section{Conclusion}

EC is a multi-step and complex process caused by the contribution of many factors. In this research, P53, P16, Cyclin D1 and Ki67 are the cell cycle relate
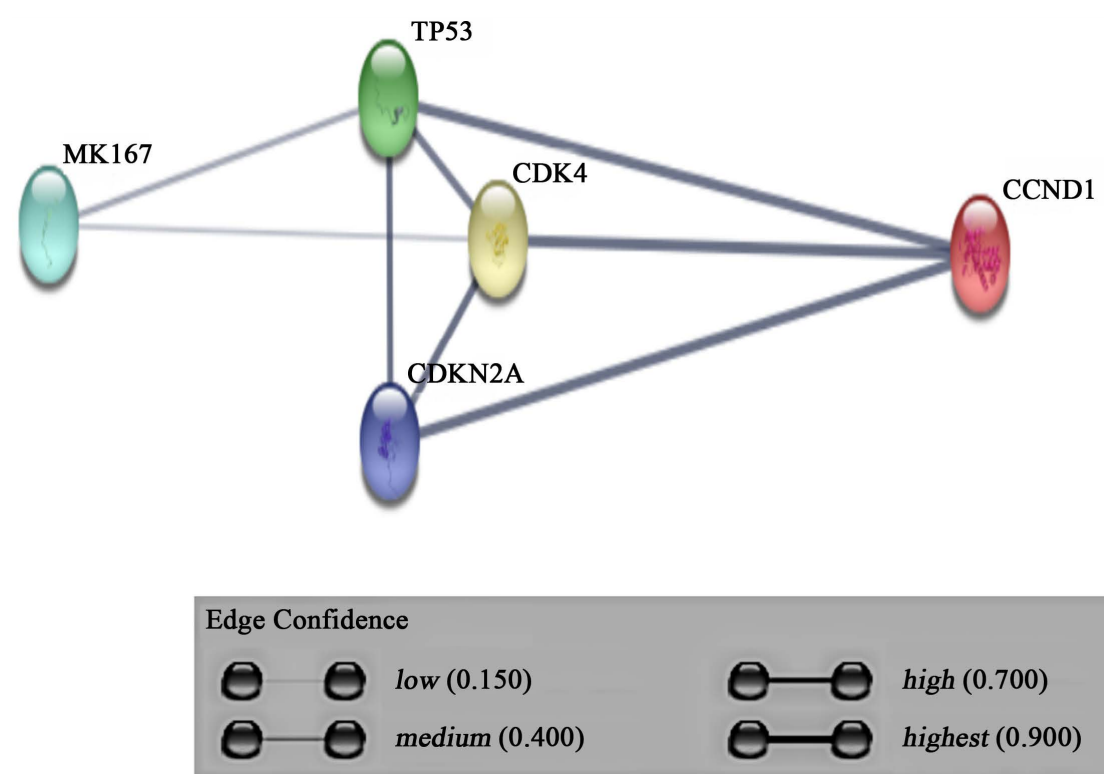

Figure 2. P53, P16, Cyclin D1 and Ki67 stringing. There is no direct relation between MKI67 (KI67) and cell cycle relative proteins ccnd1 (cyclin D1) and CDKN2A (P16). And a dim relation between KI67 and P53. and strong correlations between P53, P16, and CyclinD1. 
proteins and key targets in the loss of cell cycle control. According to previous studies, different area showed different expression rate of these proteins. The different rates of P53, P16, Cyclin D1 and Ki7 in Chaoshan are in comparison with other areas which may demonstrate the molecular basis for the geographical distribution of esophageal cancer.

\section{Acknowledgements}

This study was supported by Beijing Natural Science Foundation, Beijing University of Technology Foundation, Development Program of China and National Key Technology Support Program.

\section{Funding}

This study was supported by Beijing natural Science Foundations (Grant No. 5162003). Beijing University of Technology Foundations (Grant No. 015000514314004). Development Program of China (Grant No. 2011SLKID103). National Key Technology Support Program (Grant No. 2006BAI19B03)

\section{Availability of Data and Materials}

All available data can be obtained by contacting the corresponding author.

\section{Ethical Approval}

All procedures performed in studies involving human participants were in accordance with the ethical standards of the institutional and national research committee and with the 1964 Helsinki declaration and its later amendments or comparable ethical standards.

\section{Informed Consent}

Informed consent was obtained from all individual participants included in the study.

\section{Patient Consent for Publication}

Patient consent was obtained from all individuals in this study.

\section{Conflicts of Interest}

The authors declare that they have no competing of interest.

\section{Manuscript Materials}

The manuscript contains original material. And the content has not been published or submitted for publication elsewhere.

\section{References}

[1] Ferlay, J., Shin, H.R., Bray, F., Forman, D., Mathers, C. and Parkin, D.M. (2010) Es- 
timates of Worldwide Burden of Cancer in 2008: GLOBOCAN2008. International Journal of Cancer, 127, 2893-2917. https://doi.org/10.1002/ijc.25516

[2] Yang, C.S. (1980) Research on Esophageal Cancer in China: A Review. Cancer Research, 40, 2633-2644.

[3] Hongo, M., Nagasaki, Y. and Shoji, T. (2009) Epidemiology of Esophageal Cancer: Orient to Occident. Effects of Chronology, Geography and Ethnicity. Journal of Gastroenterology and Hepatology, 24, 729-735. https://doi.org/10.1111/j.1440-1746.2009.05824.x

[4] Cheung, W.Y. and Liu, G. (2009) Genetic Variations in Esophageal Cancer Risk and Prognosis. Gastroenterology Clinics of North America, 38, 75-91. https://doi.org/10.1016/j.gtc.2009.01.009

[5] Wang, L.D., Zhou, F.Y., Li, X.M., Sun, L.D., Song, X., Jin, Y., Li, J.M., Kong, G.Q., Qi, H. and Cui, J. (2014) Corrigendum: Genome-Wide Association Study of Esophageal Squamous Cell Carcinoma in Chinese Subjects Identifies Susceptibility Loci at PLCE1 and C20orf54. Nature Genetics, 42, 759-763. https://doi.org/10.1038/ng.648

[6] Solomon, H., Brosh, R., Buganim, Y. and Rotter, V. (2010) Inactivation of the p53 Tumor Suppressor Gene and Activation of the Ras Oncogene: Cooperative Events in Tumorigenesis. Discovery Medicine, 9, 448-454.

[7] Henley, S.A. and Dick, F.A. (2012) The Retinoblastoma Family of Proteins and Their Regulatory Functions in the Mammalian Cell Division Cycle. Cell Division, 7, 10. https://doi.org/10.1186/1747-1028-7-10

[8] Dong, M., Nio, Y., Tamura, K., Song, M.M., Guo, K.J., Guo, R.X. and Dong, Y.T. (2000) Ki-ras Point Mutation and p53 Expression in Human Pancreatic Cancer: A Comparative Study among Chinese, Japanese, and Western Patients. Cancer Epidemiology, Biomarkers \& Prevention, 9, 279-284.

[9] Huang, K., Cen, L., Zhang, J., Wu, Z., Lan, L., Wang, L., Lu, B. and Liu, Y. (2014) Elevated p53 Expression Levels Correlate with Tumor Progression and Poor Prognosis in Patients Exhibiting Esophageal Squamous Cell Carcinoma. Oncology Letters, 8, 1441-1446. https://doi.org/10.3892/ol.2014.2343

[10] Naga Deepthi, C.H., Pavan Kumar, V.V.L., Rameshbabu, A. and Indirapriyadarshini, U. (2011) Role of Tumor Suppressor Protein p53 in Apoptosis and Cancer Therapy. Journal of Cancer Science and Therapy, S17, 001. https://doi.org/10.4172/1948-5956.S17-001

[11] Reisman, D., Takahashi, P., Polson, A. and Boggs, K. (2012) Transcriptional Regulation of the p53 Tumor Suppressor Gene in S-Phase of the Cell-Cycle and the Cellular Response to DNA Damage. Biochemistry Research International, 808934.

[12] Liu, Y. and Bodmer, W.F. (2006) Analysis of P53 Mutations and Their Expression in 56 Colorectal Cancer Cell Lines. Proceedings of the National Academy of Sciences of the United States of America, 103, 976-981.

https://doi.org/10.1073/pnas.0510146103

[13] Naccarati, A., Polakova, Y.V., Pardini, Y.B., Vodickova, L., Hemminki, K., Kumar, R. and Vodicka, P. (2012) Mutations and Polymorphisms in TP53 Gene-An Overview on the Role in Colorectal Cancer. Tagenesis, 27, 211-218. https://doi.org/10.1093/mutage/ger067

[14] Sionov, R.V., Hayon, I.L. and Haupt, Y. (2001) The Regulation of p53 Growth Suppression Austin: Landes Bioscience. Madame Curie Bioscience Database, 106-125.

[15] Milner, J. and Medcalf, E.A. (1991) Cotranslation of Activated Mutant p53 with wild Type Drives the Wild-Type p53 Protein into the Mutant Conformation. Cell, 
65, 765-774. https://doi.org/10.1016/0092-8674(91)90384-B

[16] Bálint, E. and Vousden, K.H. (2001) Activation and Activities of the p53 Tumour Suppressor Protein. British Journal of Cancer, 85, 1813-1823.

https://doi.org/10.1054/bjoc.2001.2128

[17] Smith, E.M., Rubenstein, L.M., Hoffman, H., Haugen, T.H. and Turek, L.P. (2010) Human Papillomavirus, p16 and p53 Expression Associated with Survival of Head and Neck Cancer. Infectious Agents and Cancer, 5, 4. https://doi.org/10.1186/1750-9378-5-4

[18] Serrano, M., Hannon, G.J. and Beach, D. (1993) A New Regulatory Motif in Cell-Cycle Control Causing Specific Inhibition of Cyclin D/CDK4. Nature, 366, 704-707. https://doi.org/10.1038/366704a0

[19] Enders, G.H., Koh, J., Missero, C., Rustgi, A.K. and Harlow, E. (1996) p16 Inhibition of Transformed and Primary Squamous Epithelial Cells. Oncogene, 12, $1239-1245$.

[20] Foster, J.S., Henley, D.C., Bukovsky, A., Seth, P. and Wimalasena, J. (2001) Multifaceted Regulation of Cell Cycle Progression by Estrogen: Regulation of Cdk Inhibitors and Cdc25A Independent of Cyclin D1-Cdk4 Function. Molecular and Cellular Biology, 21, 794-810. https://doi.org/10.1128/MCB.21.3.794-810.2001

[21] Deng, H.Y., Chen, Z.H., Wang, Z.Q., Wang, Y.C., Li, E.M., Xu, L.Y., Lin, Y.D. and Chen, L.Q. (2017) High Expression of Ki-67 Is an Independent Favorable Prognostic Factor for Esophageal Small Cell Carcinoma. Oncotarget, 8, 55298-55307. https://doi.org/10.18632/oncotarget.19426

[22] Zatonski, T., Ciesielska, U., Nowinska, K., Ratajczak-Wielgomas, K., Kobierzycki, C., Pula, B., Podhorska-Okolow, M., Krecicki, T. and Dziegiel, P. (2016) Expression of Cell Cycle-Related Proteins p16, p27, p53 and Ki-67 in HPV-Positive and -Negative Samples of Papillomas of the Upper Respiratory Tract. Anticancer Research, 36, 3917-3924.

[23] Mohammadzad Mehryar, M., Li, S.Y., Liu, H.W., Li, F., Zhang, F., Zhou, Y.B., Zeng, Y. and Li, J.T. (2015) Prevalence of Human Papillomavirus in Esophageal Carcinoma in Tangshan, China. World Journal of Gastroenterology, 21, 2905-2911. https://doi.org/10.3748/wjg.v21.i10.2905

[24] Xu, H., Lu, D.W., El-Mofty, S.K. and Wang, H.L. (2004) Metachronous Squamous Cell Carcinomas Evolving from Independent Oropharyngeal and Pulmonary Squamous Papillomas: Association with Human Papillomavirus 11 and Lack of Aberrant p53, Rb, and p16 Protein Expression. Human Pathology, 35, 1419-1422. https://doi.org/10.1016/j.humpath.2004.06.003

[25] Portari, E.A., Russomano, F.B., de Camargo, M.J., Machado Gayer, C.R., da Rocha Guillobel, H.C., Santos-Rebouças, C.B. and Brito Macedo, J.M. (2013) Immunohistochemical Expression of Cyclin D1, p16Ink4a, p21WAF1, and Ki-67 Correlates with the Severity of Cervical Neoplasia. International Journal of Gynecological Pathology, 32, 501-508. https://doi.org/10.1097/PGP.0b013e31826f5cf6

[26] Ortiz, A.B., Garcia, D., Vicente, Y., Palka, M., Bellas, C. and Martin, P. (2017) Prognostic Significance of Cyclin D1 Protein Expression and Gene Amplification in Invasive Breast Carcinoma. PLoS ONE, 12, e0188068.

https://doi.org/10.1371/journal.pone.0188068

[27] Jayasurya, R., Francis, G., Kannan, S., Lekshminarayanan, K., Nalinakumari, K.R., Abraham, T., Abraham, E.K. and Nair, M.K. (2004) p53, p16 and cyclinD1: Molecular Determinants of Radiotherapy Treatment Response in Oral Carcinoma. International Journal of Cancer, 109, 710-716. https://doi.org/10.1002/ijc.20042 
[28] Kim, S.A., Ryu, Y.W., Kwon, J.I., Choe, M.S., Jung, J.W. and Cho, J.W. (2017) Differential Expression of Cyclin D1, Ki-67, pRb, and p53 in Psoriatic Skin Lesions and Normal Skin. Molecular Medicine Reports, 17, 735-742.

[29] Papadopoulos, O., Betsi, E. and Tsakistou, G. (2007) Expression of Cyclin D1 and Ki-67 in Squamous Cell Carcinoma of the Penis. Anticancer Research, 27, 2167-2174.

[30] Shin, E., Jung, W.H. and Koo, J.S. (2015) Expression of p16 and pRB in Invasive Breast Cancer. International Journal of Clinical and Experimental Pathology, 8, 8209-8217.

[31] Mathew, R., Arora, S., Khanna, R., Mathur, M., Shukla, N.K. and Ralhan, R. (2002) Alterations in p53 and pRb Pathways and Their Prognostic Significance in Oesophageal Cancer. European Journal of Cancer, 38, 832-841. https://doi.org/10.1016/S0959-8049(02)00007-2

[32] Yang, G., Zhang, Z., Liao, J., Seril, D., Wang, L., Goldstein, S. and Yang, C.S. (1997) Immunohistochemical Studies on Waf1p21, p16, pRb and p53 in Human Esophageal Carcinomas and Neighboring Epithelia from a High-Risk Area in Northern China. International Journal of Cancer, 72, 746-751. https://doi.org/10.1002/(SICI)1097-0215(19970904)72:5<746::AID-IJC7>3.0.CO;2-S

[33] Bai, P., Xiao, X., Zou, J., Cui, L., Bui Nguyen, T.M., Liu, J., Xiao, J., Chang, B., Wu, J. and Wang, H. (2012) Expression of p14ARF, p15INK4b, p16INK4a and skp2 Increases during Esophageal Squamous Cell Cancer Progression. Experimental and Therapeutic Medicine, 3, 1026-1032. https://doi.org/10.3892/etm.2012.523

[34] Wang, D.Y., Xiang, Y.Y., Tanaka, M., Li, X.R., Li, J.L., Shen, Q., Sugimura, H. and Kino, I. (1994) High Prevalence of p53 Protein Overexpression in Patients with Esophageal Cancer in Linxian, China and Its Relationship to Progression and Prognosis. Cancer, 74, 3089-3096. https://doi.org/10.1002/1097-0142(19941215)74:12<3089::AID-CNCR2820741205> 3.0.CO;2-N

[35] Wang, L.D., Zhou, Q., Zhang, Y.C., Li, X.F., Wang, W.P., He, L., Gao, S.S. and Li, Y.X. (1997) Alterations in p53 Expression and Cell Proliferation in Esophageal Epithelia among Patients from Geographical Areas with High or Low Incidence of Esophageal Cancer. World Journal of Gastroenterology, 3, 80.

[36] Angiero, F., Berenzi, A., Benetti, A., Rossi, E., Del Sordo, R., Sidoni, A., Stefani, M. and Dessy, E. (2008) Expression of p16, p53 and Ki-67 Proteins in the Progression of Epithelial Dysplasia of the Oral Cavity. Anticancer Research, 28, 2535-2539.

[37] Kato, J., Matsushime, H., Hiebert, S.W., Ewen, M.E. and Sherr, C.J. (1993) Direct Binding of Cyclin D to the Retinoblastoma Gene Product (pRb) and pRb Phosphorylation by the Cyclin D-Dependent Kinase CDK4. Genes \& Development, 7, 331-342. https://doi.org/10.1101/gad.7.3.331

[38] Gartel, A.L. and Tyner, A.L. (2002) The Role of the Cyclin-Dependent Kinase Inhibitor p21 in Apoptosis. Molecular Cancer Therapeutics, 1, 639-649.

[39] Peter, M. and Herskowitz, I. (1994) Joining the Complex: Cyclin-Dependent Kinase Inhibitory Proteins and the Cell Cycle. Cell, 79, 181-184. https://doi.org/10.1016/0092-8674(94)90186-4

[40] Sherr, C.J. and McCormick, F. (2002) The RB and p53 Pathways in Cancer. Cancer Cell, 2, 103-112. https://doi.org/10.1016/S1535-6108(02)00102-2

[41] Sano, T., Oyama, T., Kashiwabara, K., Fukuda, T. and Nakajima, T. (1998) Expression Status of p16 Protein Is Associated with Human Papillomavirus Oncogenic Potential in Cervical and Genital Lesions. The American Journal of Pathology, 153, 
1741-1748. https://doi.org/10.1016/S0002-9440(10)65689-1

[42] Sgaramella, N., Coates, P.J., Strindlund, K., Sgaramella, N., Coates, P.J., Strindlund, K., Loljung, L., Colella, G., Laurell, G., Rossiello, R., Muzio, L.L., Loizou, C. and Tartaro, G. (2015) Expression of p16 in Squamous Cell Carcinoma of the Mobile Tongue Is Independent of HPV Infection Despite Presence of the HPV-Receptor Syndecan-1. British Journal of Cancer, 113, 321-326.

https://doi.org/10.1038/bjc.2015.207 